\title{
GCU
}

Glasgow Caledonian

University

University for the Common Good

\section{The effect of environmental factors on the development of pine root systems}

\section{Mickovski, Slobodan B.}

\section{Published in:}

Recent Advances in Environmental Science from the Euro-Mediterranean and Surrounding Regions

DOI:

10.1007/978-3-319-70548-4_346

Publication date:

2018

Document Version

Author accepted manuscript

Link to publication in ResearchOnline

Citation for published version (Harvard):

Mickovski, SB 2018, The effect of environmental factors on the development of pine root systems. in Recent Advances in Environmental Science from the Euro-Mediterranean and Surrounding Regions. Advances in Science, Technology \& Innovation, Springer, pp. 1193-1195, Euro-Mediterannean Conference for Environmental Integration, Sousse, Tunisia, 22/12/17. https://doi.org/10.1007/978-3-319-70548-4_346

\section{General rights}

Copyright and moral rights for the publications made accessible in the public portal are retained by the authors and/or other copyright owners and it is a condition of accessing publications that users recognise and abide by the legal requirements associated with these rights.

Take down policy

If you believe that this document breaches copyright please view our takedown policy at https://edshare.gcu.ac.uk/id/eprint/5179 for details of how to contact us. 


\title{
The effect of environmental factors on the development of pine root systems
}

\author{
Slobodan B. Mickovski ${ }^{1}$ \\ ${ }^{1}$ Glasgow CaledonianUniversity, Scotland, UK
}

Highlights: The effects of soil strength and temperature were investigated on young seedlings of two pine species. The rate of axial development of root systems of both species decreased with the increase in soil compaction, while both species had the largest increase in axial length at $15^{\circ} \mathrm{C}$, which might be close to the optimal temperature for root elongation rate. These differences in the form and behaviour of the root systems of the two pines might be important for competition and integration of the species into the environmental management strategies.

Keywords: Pinus peuce, Pinus sylvestris, roots, soil compaction, temperature, axial growth, lateral growth

\section{Introduction}

It is well known that two of the principal soil physical factors that affect root growth are its mechanical strength and temperature. Soil compaction, which results in mechanical impedance that might restrict root growth, arises from mainly externally applied forces such as trampling by animals or farm and tillage equipment and even a small incerease in compaction can result in large decrease in root growth and major changes in root morphology. The type of soil strength characteristics that are favourable to plant growth are closely connected with the nature of the plant (Gonzalez-Ollauri and Mickovski, 2017a) and the temperature at which it grows. Root systems grown in low temperatures are often smaller and less branched which means they exploit a smaller soil volume for plant nutrients and water, and are expected to require a higher uptake rate of nutrients and water per unit length to keep up with the demand.

Despite the wide coverage of the effects of mechanical impedance on root growth and development in the literature (Stokes et al, 2014), almost all studies have concentrated on crops or other fast growing plants. Similarly, only a few investigations have been focused on the influence of temperature on root extension or lateral root proliferation in trees. This study is an attempt to investigate the root development of two Pinus species common to the Mediterranean region, grown in different soil consistencies and temperatures and to explore the influence of temperature and soil compaction on the axial and lateral root development. The results of this study might deepen the knowledge on the most important factors influencing root development in the early stages of growth, and will surely add to the number of new tree species investigated. Additionally, the results of this study will enable the foresters and eco-engineerins in the Mediterranean region to assess the potential of these pine species for remediation of natural disasters such as forest fires, erosion and landsides.

\section{Material and Methods}

Ninety 2-year-old Scots pine (Pinus sylvestris) and 90 Macedonian pine (Pinus peuce) seedlings were planted in containers containing brown humus soil (clayey sand with organic matter of $20 \%$ by weight) sieved through $2 \mathrm{~mm}$ sieve and with dry weight of $1.9 \mathrm{~kg} \mathrm{~m}-3$. Three containers with 10 seedlings each were packed using $300 \mathrm{~J} \mathrm{~m}-3$ compaction energy per pot (compact soil), another three using $150 \mathrm{~J} \mathrm{~m}-3$ compaction energy per pot (semicompact soil) and the last three without compactio (loose soil). The plants were grown in three separate glasshouse cublicles with 12 hour daylight growing conditions and at a constant temperature $\left(15^{\circ} \mathrm{C}, 20^{\circ} \mathrm{C}\right.$, and $25^{\circ} \mathrm{C}$ respectively). Containers were arranged so that there were ten seedlings of each species in compact, semicompact and loose soil at each of the three different temperatures.

The resistance of the soil to static penetration was tested using a pocket penetrometer at four different depths: $2.5 \mathrm{~cm}, 5 \mathrm{~cm}, 7.5 \mathrm{~cm}$, and $10 \mathrm{~cm}$. The root system architecture and distribution were recorded before planting and after 3 months growth, together with the maximum axial length of the root system, number of 'major' laterals (defined as lateral roots longer than $20 \mathrm{~mm}$ ) per seedling, and the root diameter $5 \mathrm{~cm}$ below the root apex of 
every seedling. Analysis of variance (ANOVA) was then used to calculate the significance of different factors (species, temperature, soil consistence) on the axial root growth of the seedlings, as well as on the increase of the number of major laterals over time.

\section{Results and Discussion}

Penetrometer readings showed an increase in penetration resistance (soil compaction) with depth ranging from $0.981 \mathrm{kPa}$ for loose soil at $2.5 \mathrm{~cm}$ depth, to $25.01 \mathrm{kPa}$ for compact soil at $10 \mathrm{~cm}$ depth. The greatest differences in soil density were found in the uppermost layers of the soil where the majority of roots were located.

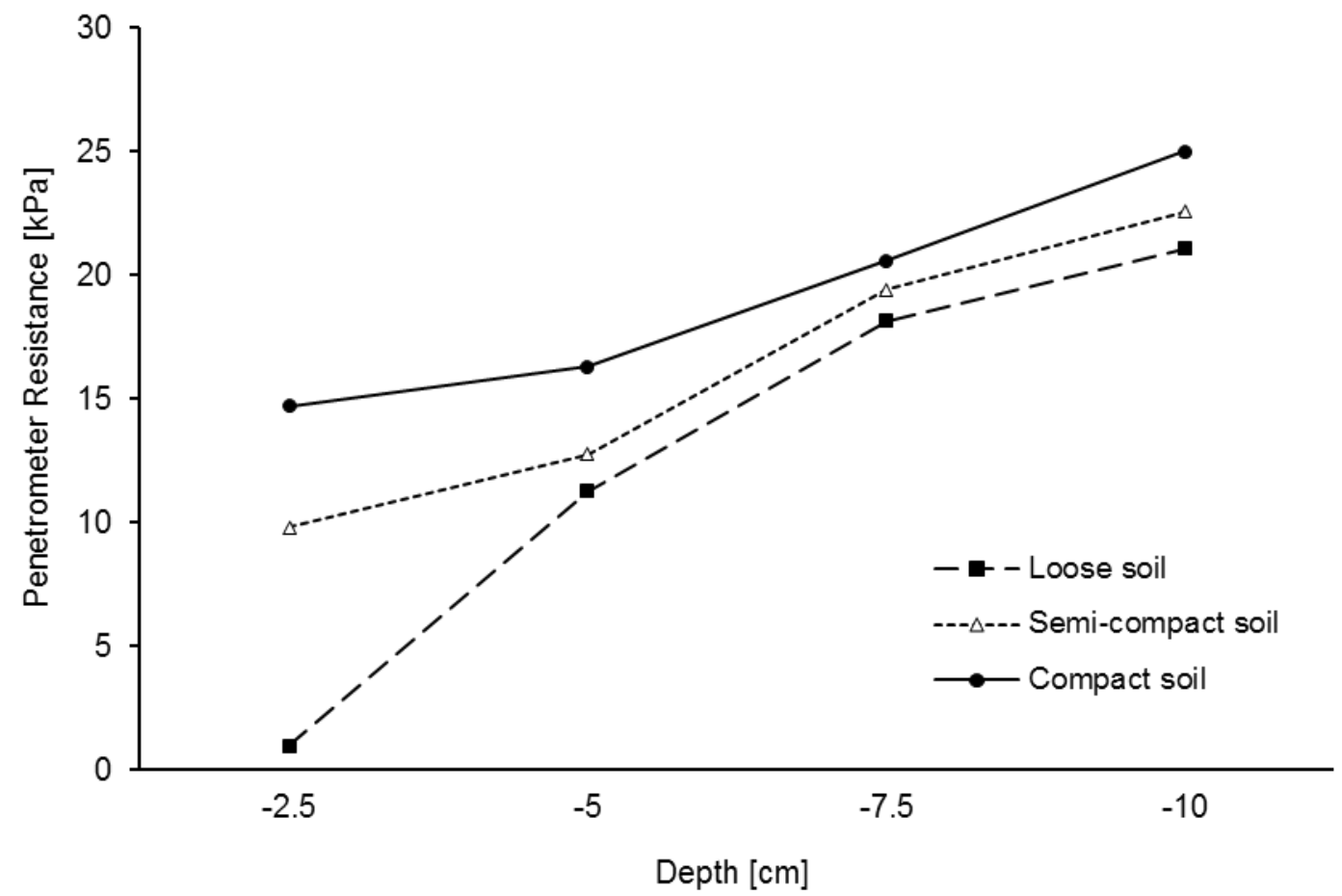

Figure 1 . Soil penetration resistance with depth in the three differently compacted soils.

The growth rate for both pine species (Figure 2) was affected by three factors: the species, degree of soil compaction, and temperature.
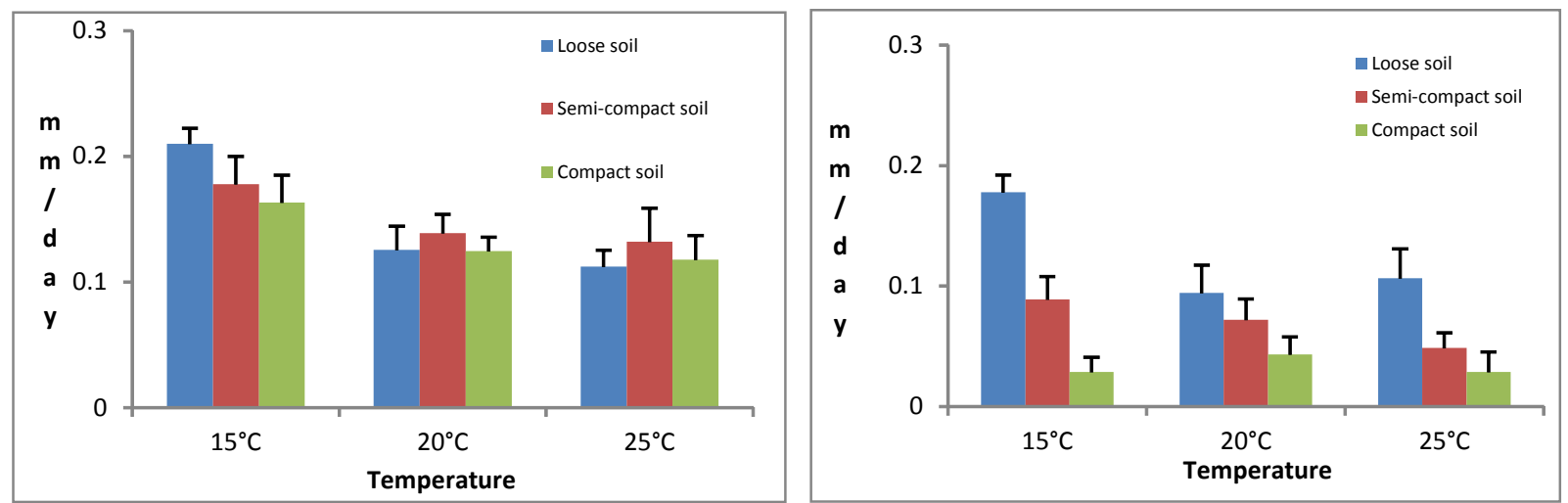

Figure 2. Average axial root growth rate of a) Pinus sylvestris and b) Pinus peuce seedlings grown at three different temperatures $\left(15^{\circ} \mathrm{C}, 20^{\circ} \mathrm{C}\right.$, and $25^{\circ} \mathrm{C}$ ) and in three different soil consistencies (loose, semi-compact, compact). Error bars indicate + SD.

The average rate of axial growth for $P$. sylvestris was higher than the average axial increase slope for $P$. peuce. Loose soil enabled a greater mean increase in axial root length for the seedlings of both species. This was always followed by the increase 
of the root length of the seedlings grown in semi-compacted and compacted soil. The seedlings grown at $15^{\circ} \mathrm{C}$ had greatest mean increase in the axial length of their roots for both species, followed by the ones grown at $20^{\circ} \mathrm{C}$ and at $25^{\circ} \mathrm{C}$ which had elongated least of all. The two-way ANOVA also showed that there was no significant interaction ( $p>0.05)$ between temperature and soil consistency in either species. The average increase in the number of new major laterals for $P$. peuce seedlings was significantly lower than the average increase in the number of major laterals for $P$. sylvestris. The rates of increase of radial root diameter showed a tendency to increase with increase in the soil compactness and temperature

\section{Conclusion}

This study showed both similarities and differences in the root growth in two Pinus species subjected to different soil consistencies and temperatures. The similarities lay in the fact that the rate of axial development of the root systems of both species decreased with an increase in soil compaction (though this was not statistically significant in $P$. sylvestris), even though the levels of compaction were well below the maximum roots are capable of withstanding which is consistent with previous studies (Mickovski and Ennos, 2003). Both species also had the largest increase in axial length of their root systems at $15^{\circ} \mathrm{C}$, which might be due to the optimal temperature for root elongation rate. Furthermore, in both species, soil consistency had no significant effect on lateral root proliferation; they overcome even the strongly compacted soil. The differences between the species lay in the extent of lateral root proliferation. While $P$. sylvestris proliferated fewer laterals as the temperature increased, the temperature seemed to be a non-significant factor in the lateral root development of $P$. peuce seedlings.

This study showed that the root elongation rate is negatively correlated with mechanical impedance of the soil since the elongation was lowest in the compacted media and increased as the soil compaction level decreased. The decrease of the elongation rate with the compaction might result from the reduction in the rate of cell elongation and possibly from a decrease in cell production rate. It might also be a result of a smaller difference between the cell pressure and the resistance offered by the soil matrix. Bearing in mind that the roots penetrate soil by an alternating series of radial and axial enlargements, it is clear that they have to overcome soil mechanical resistance in both the axial and radial direction, and/or adapt and change physiologically to the stresses encountered as argued by Mickovski and Ennos (2003). Root growth is thus expected to be very slow during early growth, since the plant will still be suffering from a plant check or time lag in production of adventitious roots.

The variation in elongation rates for various plants reflect the genetic difference among species as well as the effects of other factors such as root system architecture (Tardio et al, 2016). This is important for competition between species and for allowing one genotype to grow better than the other at a specific location. This is also important because both pine species investigated are common to the Mediterranean region (Savill and Mason 2015) where they can be used for prevention and mitigation of natural disasters such as forest fires, erosion and landslides. The results of this study could be applied for other tree species that encounter particularly dense soil conditions in some Mediterranean soils or to allow foresters and landcape managers to select appropriate species for specific climate and soil condition in order to achieve the environmental and engineering effects such as stability, sustainability and resilience (Mickovski and Thomson, 2016; Gonzalez-Ollauri and Mickovski, 2017b).

\section{References}

Gonzalez-Ollauri, A. and Mickovski, S.B., 2017. Hydrological effect of vegetation against rainfall-induced landslides. Journal of Hydrology, 549 (374-387);

Gonzalez-Ollauri, A. and Mickovski, S.B., 2017. Shallow landslides as drivers for slope ecosystems evolution and biophysical diversity. Landslides, DOI 10.1007/s10346-017-0822-y

Mickovski, S.B. and Ennos, R.A. 2003. Anchorage and asymmetry in the root system of Pinus peuce. Silva Fennica 37(2): 161-173

Mickovski, S B and Thomson, C S. 2016. Innovative Approach in the Stabilisation and Erosion Protection of Coastal Slopes in Scotland. Coastal Management (Jan. 2016), 587-596

Savill, P. and Mason, B. 2015. Pinus peuce Griseb., Macedonian or Balkan pine. Quarterly jounral of Forestry, 109(4): 245-252.

Stokes, A et al. 2014. Ecological mitigation of hillslope instability: ten key issues facing researchers and practitioners. Plant and Soil 377(1-2): 1-23

Tardio, G., González-Ollauri A and Mickovski S.B. 2016. A non-invasive preferential root distribution analysis methodology from a slope stability approach. Ecological Engineering 97: 46-57. 